\title{
The latest results from the technological and typological analysis of chipped stone assemblages from Ilipinar, Pendik, Fikir tepe and Menteşe, NW Turkey
}

\author{
Ivan Gatsov \\ New Bulgarian University, Archaeological Institute and Museum, BAS, Sofia, BG \\ igatsov@yahoo.com
}

\begin{abstract}
The papers presents the latest results from the technological and typological analysis of chipped stone assemblages from Ilipinar, Pendik, Fikir tepe, and Mentese in NW Turkey. The stone industry of Ilipinar shows parallels with the chipped stone material from Fikir tepe. At Ilipinar the period of technological and raw material changes in Bulgarian Thrace correspond to the end of phase $V-A$ and to the whole $V-B$, but the technological and typological features are completely different.

IZVLEČEK - V članku predstavimo najnovejše rezultate tehnoloških in tipoloških analiz kamenega orodja iz najdišč Ilipinar, Pendik, Fikir tepe in Mentese na severozahodu Turčije. Kamena industrija iz Ilipinarja kaže podobnosti s kamenim materialom z najdišča Fikir tepe. Na najdišču Ilipinar obdobje tehnoloških sprememb in sprememb surovine $v$ bolgarski Trakiji odgovarja koncu faze $V-A$ in celotna faza $V-B$, toda tehnološke in tipološke značilnosti so popolnoma drugačne.
\end{abstract}

KEY WORDS - core; flake and blade manufacturing; tool; retouch

The main information concerning the sites mentioned below can be found in the work of J. Roodenberg (Roodenberg 1995; Roodenberg, Thissen 2001), and M. Özdogan (Özdogan M. 1989; 1995; 1998; Gatsov 2000).

Ilipinar

The Ilipinar chipped stone industry is characterized by flake manufacturing and flake transformation into retouched tools. The other main feature is blade production, mostly used for manufacturing, the use of unmodified blades. The frequency of blade tools is low, and the blade perforators as its best diagnostic features may be considered.

In the earliest phases, $\mathrm{X}$ and IX obsidian artefacts are recorded in greater quantities, while in the remaining phases their frequency is considerably lower. The obsidian blade manufacturing was directed towards bladelet and blade production. At this stage of research in Ilipinar any downturn changes in the stone technology are observed. Although there is less material from these phases, the proportion between the categories as well as the main technological and typological characteristic in all phases of Ilipinar are similar (Figs. 1-4). The methods of obtaining raw materials and the organization of production were connected with flake core knapping off the area investigated. The predominance of butts prepared by a blow butts suggests that flake core preparation was concentrated mainly on the core platform. As a main feature of these activities, ad hoc flake manufacturing and transformation can be considered. An alternative method of organizing flint and obsidian blade manufacturing was made on spot in the area under study. It should be stressed that very a small part of this type of blank was later modified into blade retouched specimens.

Here some problems arise with the occurrence of prismatic "bullet" cores. The question is whether they can be seen as a technological indicator of an earlier technological tradition, or as a feature of 


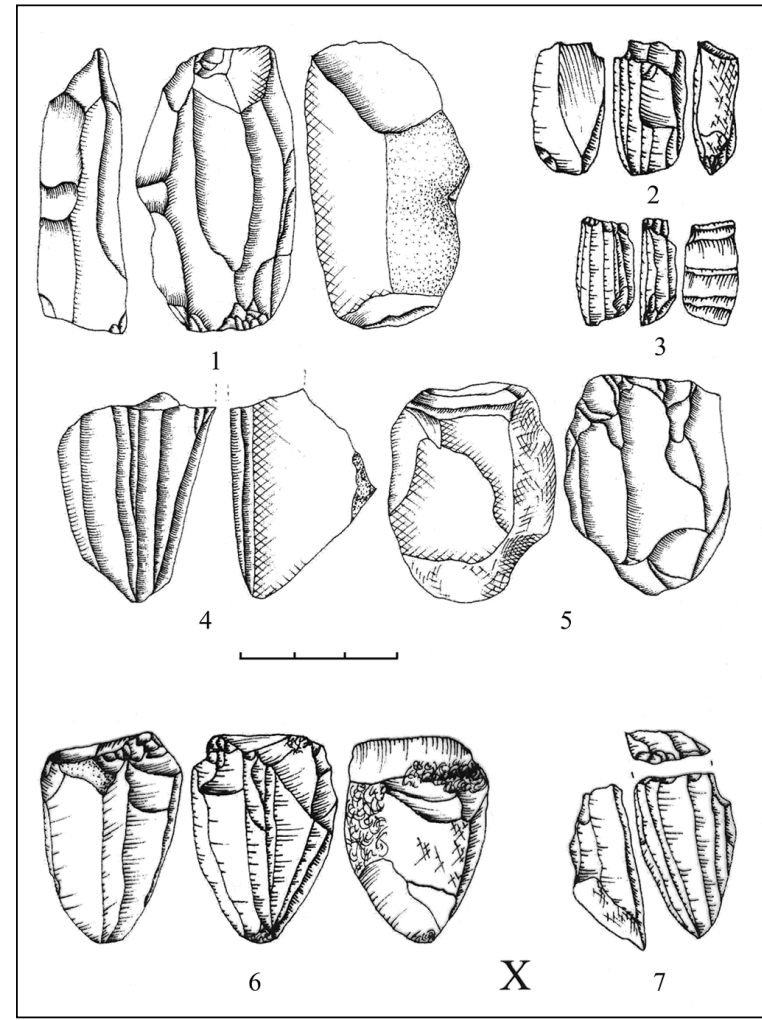

Fig. 1. Ilipinar, Phase X, 1-7 - cores.

some technological influence from other areas. The other question that arises concerns the site of this industry. Up to now the parallels with Fikir tepe are more or less established (Gatsov 2001). But how does one explain the roots of the Ilipinar industry? Where are the balance and the limits between technological traditions and functional determination?

\section{Fikir tepe}

About Fikir tepe some characteristic features can be detected. At this site two production chains are revealed. The first is linked with the exploitation of cores for flakes. The former were used for tool manufacturing and especially for flat cortical end scrapers, as well as massive ones. The other production chain is connected with blade acquisition. For this purpose, blade single platforms, as well as prismatic ones, were used. These types of cores do not fit with the more or less large flake tools. Blade tools are characterized by blade perforators with steep or semi steep retouching on the edges, partial or continuous (Fig. 5). As far the chipped stone assemblages analyzed are concerned, they probably resulted from similar methods of flake and blade production. In both cases similar to the Ilipinar the cores had been used. They reflected the above mention two types of production chains similar to the Ilipinar ones. These chains, as well as their intended products in the shape of flake end scrapers and blade perforators, show definite parallels between the Fikir tepe and Ilipinar chipped stone assemblages.

\section{Pendik}

The chipped stone material was collected from two trenches. Both collections show clear typological monotony, which is seen mainly in flake end scrapers, perforators, and retouched blades (Fig. 6). Unfortunately, the quantity of the material (debitage and retouched specimens) is not enough for more detailed comparisons, or to establish more certain parallels. At this stage of research it seems that there are certain similarities between the Pendik and Ilipinar assemblages. These parallels can be found in the similar morphological parameters of the flake end scrapers and blade perforators. The occurrence of the same type of flake end scrapers and blade perforators with steep partial retouch in Pendik and Ilipinar can be drawn. Here, the basis for searching for similarities or not can come more from ceramic and others type of finds and less from stone artefacts (Gatsov in print).

\section{Mentese}

Further below the preliminary results from the technological and typological analysis of the chipped stone artifacts from Mentese are presented. This ma-

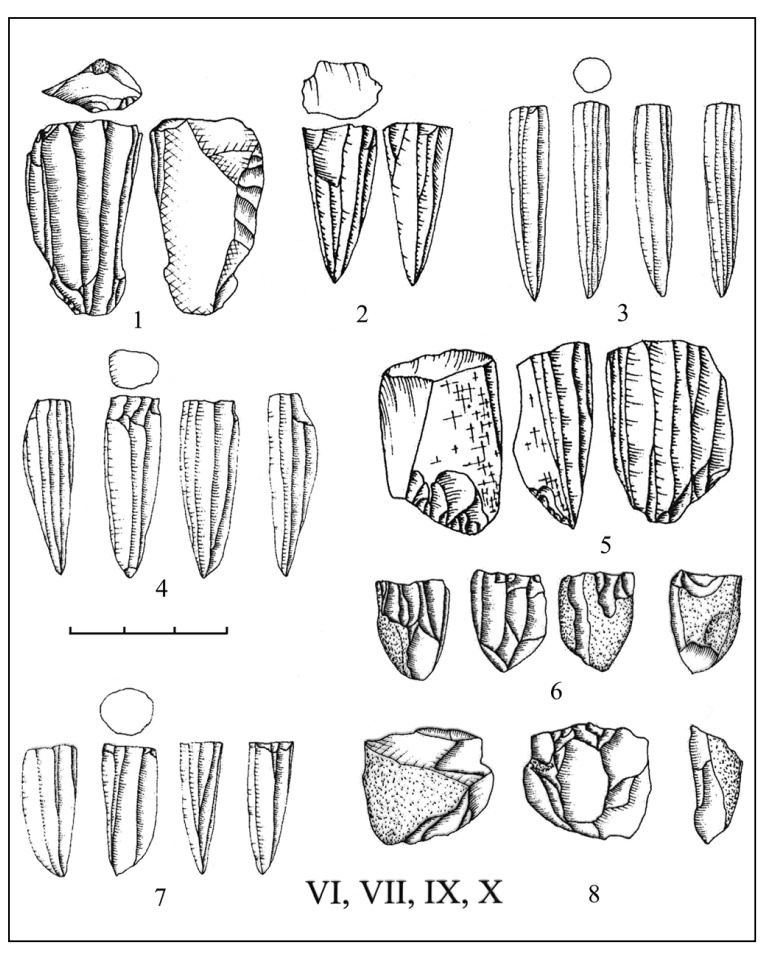

Fig. 2. Ilipinar, phases VI, VII, IX, X-cores. 


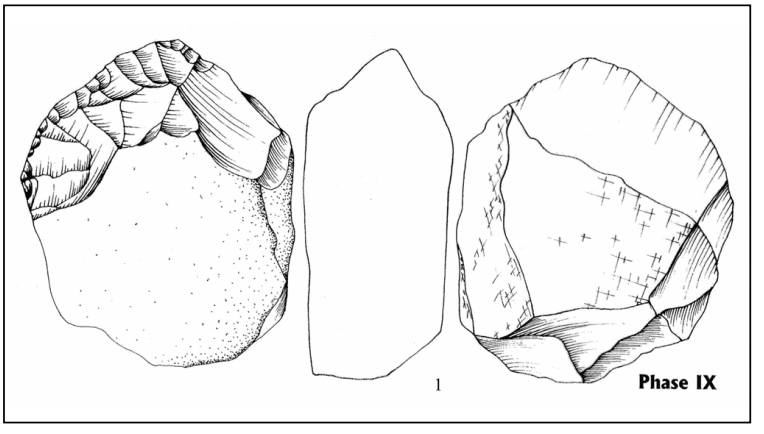

Fig. 3. Ilipinar, phase IX-macro end scraper.

terial belongs to the earlier sequence of the site, and was connected with a trench covering approximately $28 \mathrm{~m}^{2}$.

The collection contains a small quantity of flint and obsidian cores, mostly blades, fewer flakes, and very few fragments and chips. To some degree the latter may be due to the material not having been sieved. The flint and obsidian cores are presented by single platform items, mainly for blades and bladelets, and in the final stage of exploitation. Some examples are close to the prismatic ones. The core processing was carried out from one platform. Most of the cores have a flat or semi rounded striking surface. Only few items of cores with changed orientation were recorded. These were usually primary single platform cores which were transmitted in multi directional ones. In this way, all surfaces were used. As a rule,

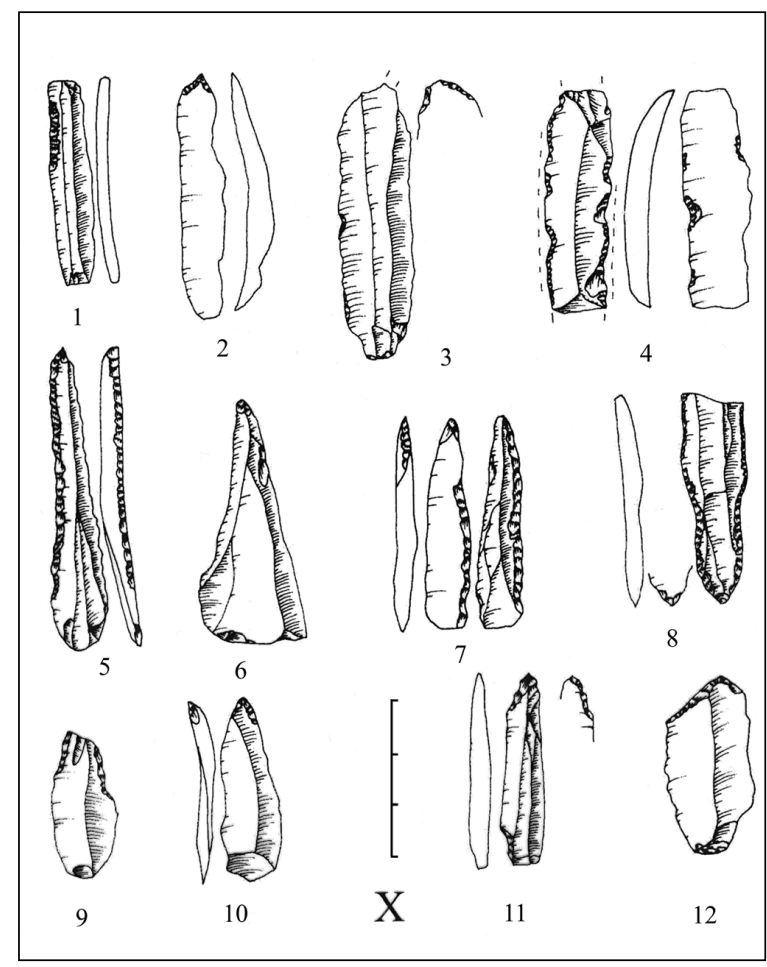

Fig. 4. Ilipinar, phase X-1-12 - perfotarors. core length was $5-7 \mathrm{~cm}$. It is characteristic that most of the predominant blades in this collection had very low thickness values. The presence of punctiform butts suggests that for blade detaching a punch was used. As was mentioned above, fragments and chips were almost entirely absent. The frequency of retouched tools is relatively small. This category is represented mostly by flake end scrapers and retouched blades (Fig. 7, Fig. 8). It is worth noticing the presence of obsidian trimming blades, as well as a massive core fragment. It is perhaps likely that core processing was done on the spot.

At the present stage of research I would like to suggest that the material from Mentese could be a little earlier than earliest phase $\mathrm{X}$ at Ilipinar.

Here it is worth adding the opinion of Dr. A. van As and Dr. M.-H. Wijnen about the Mentese pottery: "The pottery from Mentes coe Höyük, excavated in 2000 , was manufactured by a combination of modelling and coiling techniques and fired in an open fire in reducing to neutral conditions. As a result the pottery has mostly a light grey-brown to dark grey brown colour, although clear reds occur. In the upper levels deep black becomes more common. A large amount of the pottery had a high glossy burnished outer surface. In the upper levels vessels with a S-shaped profile were very common; preliminary results indicate that in the lower levels the S-shape was far less pronounced, whereas the simple plainrimmed, hole-mouth vessel became more common. Vessels had, in general, a flat base; the whole sample yielded only one ring-base. Decoration is relatively sparse - maximal $2 \%$ of the total sample. It always consists of shallow incised groves arranged in simple geometric patterns. The higher levels yielded

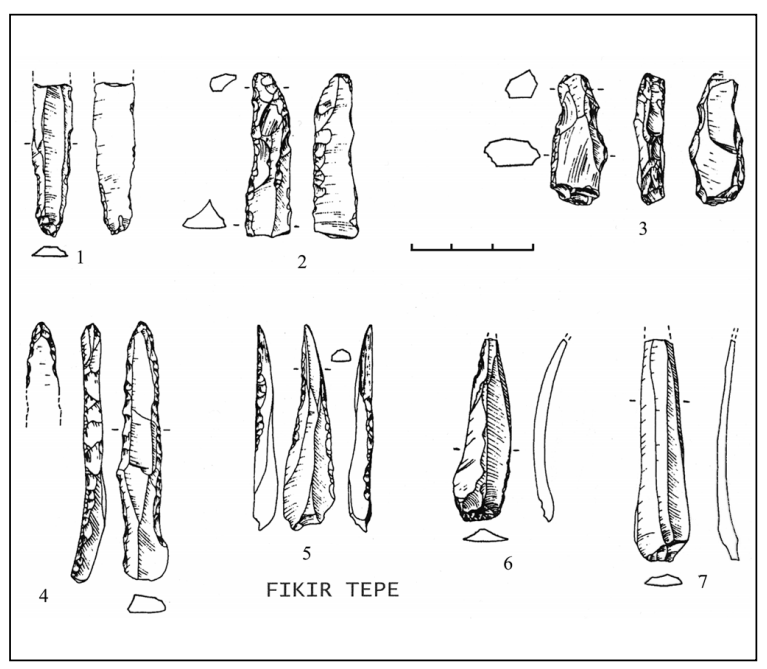

Fig. 5. Fikir tepe 1-7 perforators. 


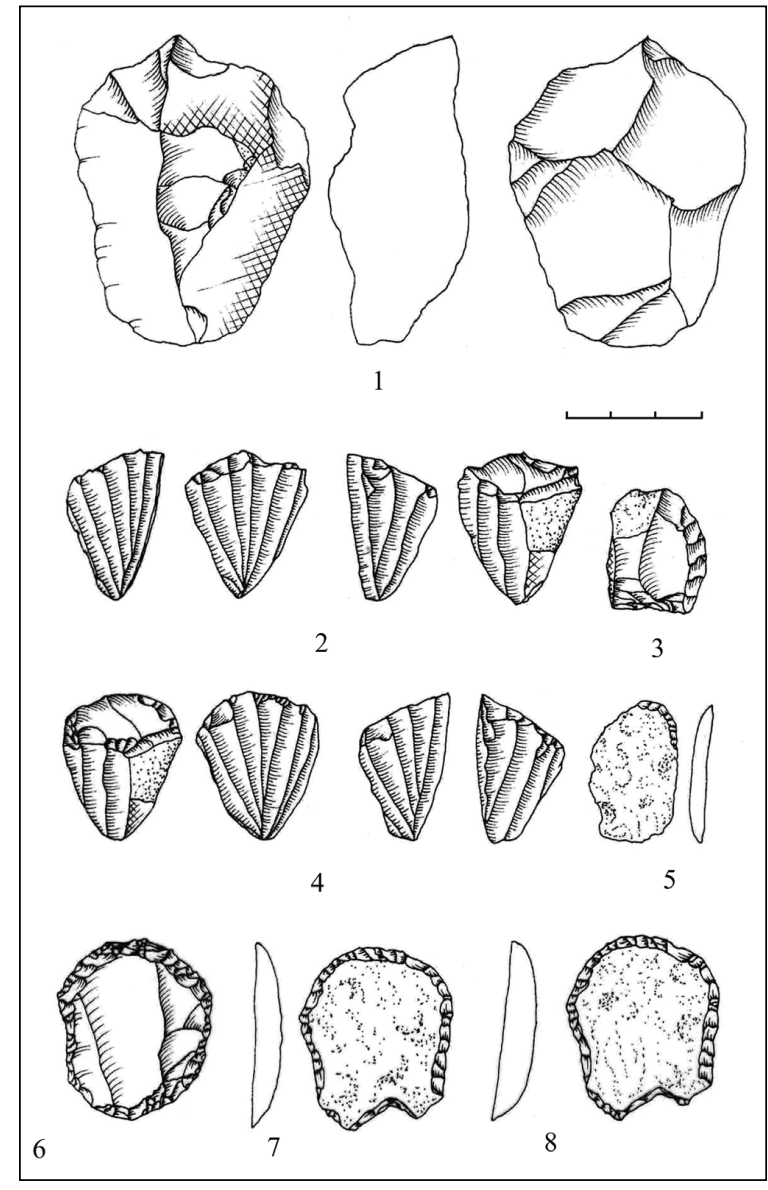

Fig. 6. Pendik 1-8 cores and end-scrapers.

also the remains of at least two rectangular boxes on feet, decorated with incised geometric patterns. Concluding, it can be said that the pottery from Mentese fits perfectly in the Fikirtepe-sequence." (This information was included in my report concerning the Mentese Höyük chipped stone collection presented at Thessaloniki $8^{\text {th }}$ EAA Annual Meeting, 2002. Here I would like to thank to Dr. M.-H. Wijnen and Dr. A. van As for their help.)

\section{CONAUSION}

In my opinion, the stone industry of Ilipinar shows undoubted parallels with the chipped stone material from Fikir tepe, but the problem is not only in looking for a synchronic connection. The main problem that arises is to what degree some of the features of the Ilipinar industry can be considered as a link between the assemblages, which are earlier or later than Ilipinar.

The main obstacle to answering this question is the weak comparative base. In West Anatolia the database is still insifficient. In Turkish Thrace few assem- blages are studied only. The lack of stratified sites from the presumably earlier Epipalaeolithic periods poses additional obstacles.

As for Epipalaeolithic sites, only the collections from the Turkish Black Sea cost can be taken into account (Gatsov and Özdogan 1994). These materials were found on the surface. They are characterized by small sized single platform cores for blades and bladelets. The core shape is defined by blank detachment executed from all striking surfaces. In my opinion, it is hard to say that definite connections exist between the Black Sea and Ilipinar collections. It is also impossible to make a comparison with the Bulgarian Early Neolithic chipped stone assemblages from Thrace. The stone material from this part of Thrace is marked by macro blade technology. As a matter of fact, flakes and flake tools are missing. There is a marked typological monotony, which consists of blades with high semi-steep or steep retouching, as well as with similar specimens with rounded ends - type Karanovo I and II. The retouched implements are represented by different modifications to the type of blanks - retouch blades, blade perforators, blade end scrapers, blade truncations. The occurrence of macro technology falls between $6000 \mathrm{BC}$ and 5500 $\mathrm{BC}$, and covers the Early Neolithic period in this area. The raw material is of a very high quality yellow flint, with or without inclusions. Probably the sour-

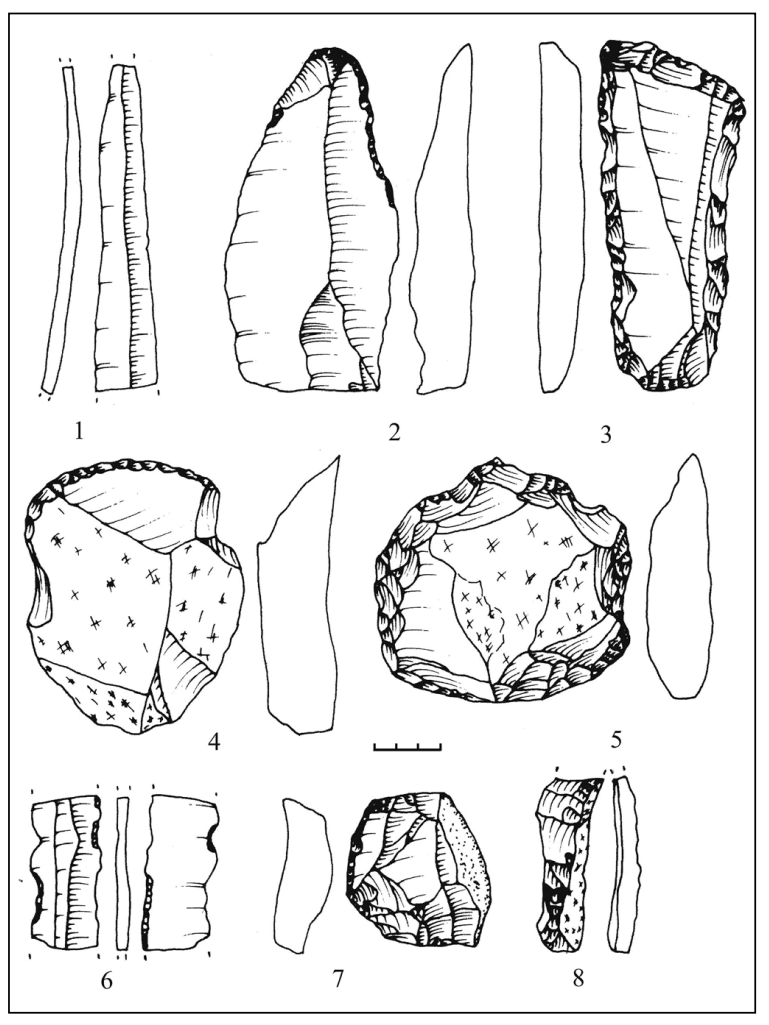

Fig. 7. Mentese 1-8 blades and retouched tools. 


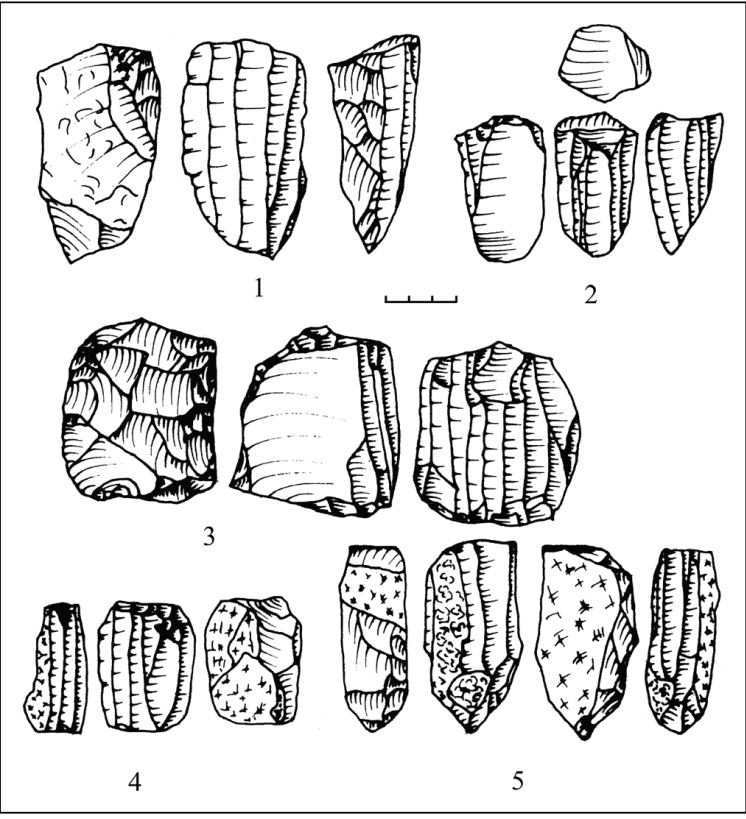

Fig. 8. Mentese 1-5 cores.

ces of this raw material lie in the region of Bulgarian Thrace - not far from the settlements of Karanovo and Azmak. Unfortunately, studies of the spatial distribution of raw materials have not been conducted (Gatsov and Kurchatov 1997).

In the region of Turkish Thrace, only a few blade macro blades have been found in phase II of Hoca Çesme (Fig. 9). Thus far the area of Karanovo and Azmak can be considered as a centre of this "macro blade area". The last is limited to the Stranga/Sakar region and the upper part of the Maritza (Meric) River in present-day Bulgaria.

Another interesting feature is linked with the decline of macro technology in the region considered. After $5500 \mathrm{BC}$ technological changes occurred in Bulgarian Thrace. The changes can be seen in a technological and typological degradation, and it has to be pointed out that the high quality yellow flint was replaced by less quality raw material. The Early Neolithic structure of raw material supply strategies, the organization of production, and the high degree of

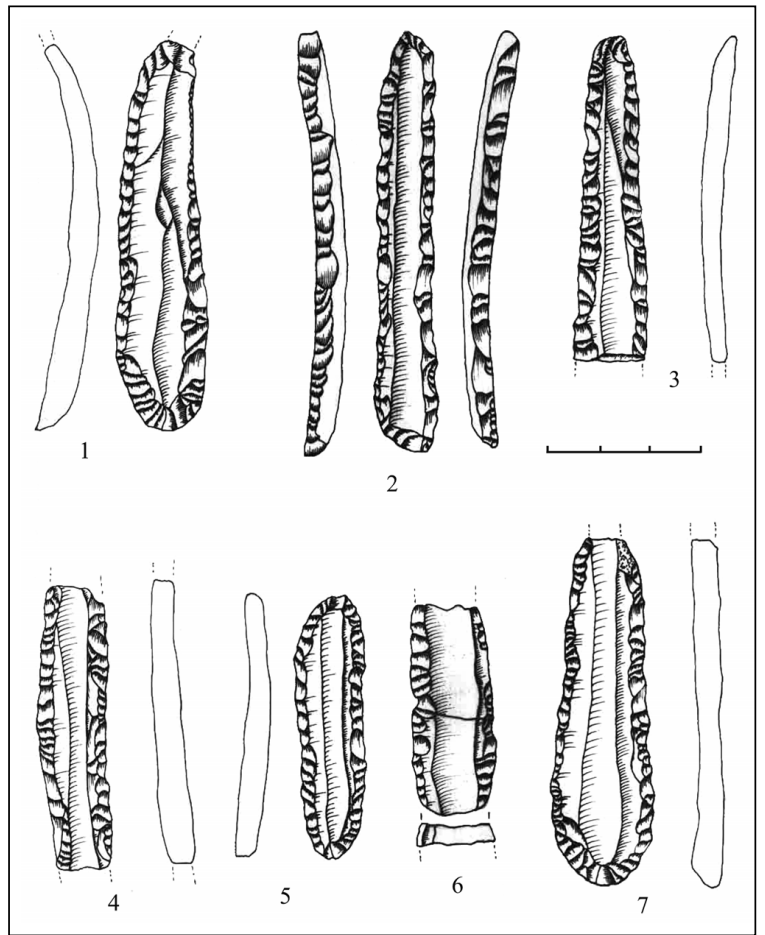

Fig. 9. Hoca Çesme 1-7 blade with high retouch.

specialization disappeared for no obvious reasons (Gatsov and Gurova 2001).

At Ilipinar the period of technological and raw material changes in Bulgarian Thrace correspond to the end of phase $\mathrm{V}-\mathrm{A}$ and to the whole of $\mathrm{V}-\mathrm{B}$, but the technological and typological features are completely different (Gatsov 2001).

The present analysis may serve in future for analytical purposes when more material becomes available, which is why this work is confined to the limits of technological and typological attributes and raw materials.

I would like to thank to Prof. Dr. M. Özdogan and Dr.
J. Roodenberg, who kindly offered the chipped stone
collections from NW Turkey to me for research.




\section{REFERENCES}

GATSOV I. 2000. Chipped stone assemblages from South Bulgaria and North - West Turkey. Epipapaeolithic/Mesolithic and Neolithic. BAR, International Series, 854: 1-28.

2001. Epipalaeolithic/Mesolithic and Neolithic Periods Chipped Stone Assemblages from Southern Bulgaria and Northwest Turkey: Similarities and Differences. TUBA - AR 4: 101-112.

(in press.) Chipped stone assemblage from Pendik, NW Turkey. In Festschrift for Prof. U. Esin. Istanbul University.

GATSOV I. and GUROVA M. 2001. Some remarks on chipped stone industries of the earliest Neolithic cultures in Bulgaria. In B. Ginter (ed.), Problems of the Stone Age in the Old World: 249-264.

GATSOV I. and KURCHATOV V. 1997. Neolithische Feursteinartefakte Osterreichisch - Bulgarische. In S. Hiller and V. Nikolov (eds.), Ausgrabungen in Karanovo. Bd. I: 213-234.
ÖZDOGAN M. 1989. Neolithic cultures of Northwestern Turkey. In S. Bokoni (ed.), Neolithic of Southeastern Europe and its Near Eastern Connections. Varia Archaeologica Hungarica II: 201-215.

1995. Neolithic in Turkey. In Reading in Prehistory. Studies presented to Halet Cambel: 53-55.

1998. Recent excavations in Eastern Thrace and Contact between the Prehistoric Cultures of Anatolia and Balkans (abstract in English). TUBA AR, 1: 63-92.

ÖZDOGAN M. and GATSOV I. 1994. Some Epi-Palaeolithic Sites in NW Turkey. Anatolica: 97-120.

ROODENBERG J. J. 1995. The Ilipinar excavation I. Five seasons in Fieldwork in NW Anatolia 19871991. Istanbul.

ROODENBERG J. J. and THISSEN L. C. (eds.) 2001. The Ilipinar Excavations II Nederlands Instituut Voor Het Nabije Oosten, Leiden. 